\title{
SCIDoC
}

International Journal of Dentistry and Oral Science (IJDOS)

ISSN: 2377-8075

\section{Management Of Tooth With Deep Furcal Defect By Endo - Perio Management - An Interdisciplinary Case Report}

Research Article

\section{Nivedhitha ${ }^{1 *}$, Swarna ${ }^{2}$}

${ }^{1}$ Professor and Head, Department of Conservative Dentistry and Endodontics, Saveetha Dental College and Hospitals, Saveetha Institute of Medical and Technical Sciences, Saveetha University, Chennai, India.

${ }^{2}$ Department of Conservative Dentistry \& Endodontics, Saveetha Dental College and Hospitals, Saveetha Institute of Medical and Technical Sciences, Saveetha University, Chennai, India.

\section{Abstract}

Multi disciplinary approach was followed in treatment of endoperio lesion in a mandibular molar with furcal involvement and apical lesion. The patient presented with pain and mobility in the right mandibular first molar. There was grade I mobility and periapical lesion along with furcal involvement in relation to 46. A probing depth of $7 \mathrm{~mm}$ was elicited in relation to buccal aspect of 46. The endodontic management of 46 was done using sonic activation of irrigant along with calcium hydroxide intracanal medicament. Periodontal flap surgery along with placement of bone graft and Platelet rich fibrin was done to facilitate healing kinetics of periapical healing as well as periodontal regeneration. The patient was recalled after 1,3,6 months and at one year follow up, complete healing of the furcal defect was seen in 46.

Keywords: Bone Graft; Calcium Hydroxide; Endo - Perio Lesion; Platelet Rich Fibrin (Prf); Sonic Irrigant Activation.

\section{Introduction}

The pulp and periodontium are interconnected embryologically, anatomically and functionally. Endo-perio lesion is a clinical manifestation of pathologic/inflammatory intercommunication between pulpal and periodontal tissues via open structures such as apical foramina, dentinal tubules and lateral accessory canals [1].

The relationship between pulp and periodontium was first discovered by Simring and Goldberg in 1964 [2]. Endodontic - periodontal problems are responsible for more than $50 \%$ of tooth mortality and the prognosis depends on identifying and eliminating the etiological factors for the disease process [3, 4]. The pathways of communication responsible for endoperio lesions include lateral and accessory canals, dentinal tubules and apical foramen [5]. Simon et al has classified endoperio lesions based on the primary origin of the disease process and the extent of involvement in the pulpal and periodontal tissues [6].

Accessory canals in the furcal area of molars paves a direct pathway of communication between the pulp and periodontium $[7,8]$. The incidence of these canals may vary from $23 \%$ to $76 \%$ [9-11]. These accessory canals communicate with pulp and periodontium by means of connective tissue and blood vessels. Accessory canals are concentrated at the apical delta region and lateral canals in the furcalregion [12]. Seltzer et al, has reported that inflammation of pulp may cause inflammatory reactions in the interradicular periodontal tissues $[13,14]$. The treatment of endoperio lesion presents a challenge to the clinician and the prognosis of a tooth with endoperio lesion depends on identifying the cause and establishing the appropriate diagnosis [15].

Disinfection of teeth with pulp necrosis and apical periodontitis is augmented with efficient irrigantactivation [16] for dislodge-

*Corresponding Author

Nivedhitha,

Professor and Head, Department of Conservative Dentistry and Endodontics, Saveetha Dental College and Hospitals, Saveetha Institute of Medical and Technical Sciences, Saveetha University, Chennai, India.

Email Id: nivedhitha.sdc@saveetha.com

Received: April 28, 2021

Accepted: May 28, 2021

Published: May 30, 2021

Citation: Nivedhitha, Swarna. Management Of Tooth With Deep Furcal Defect By Endo - Perio Management - An Interdisciplinary Case Report. Int J Dentistry Oral Sci. 2021;08(05):2666-2670. doi: http://dx.doi.org/10.19070/2377-8075-21000521

Copyright: Nivedhitha ${ }^{2021}$. This is an open-access article distributed under the terms of the Creative Commons Attribution License, which permits unrestricted use, distribution and reproduction in any medium, provided the original author and source are credited. 
ment of biofilms and debris and placement of intracanal medication facilitates increased contact time to eliminate the microbes [17]. Platelet concentrates are rich in growth factors and aid in effectively initiating the bone repair and healing by proliferation, chemotaxis and differentiation of locally derived progenitor cells [18].

Bone replacement grafts serve as a framework for blood clot formation and maturation and support the formation of bone in osseous defects [19, 20].

Previously our team has a rich experience in working on various research projects across multiple disciplines [21-35]. Now the growing trend in this area motivated us to pursue this project.

\section{Case Report}

A 24 year old male patient reported to our dental out patient department with the chief complaint of pain and mobility in the right lower back tooth for the past 3 months that pain aggravated while chewing food. Patient revealed a history of restoration in the right lower back tooth region before 5 years. The medical history was non contributory. On clinical examination, there was dislodged restoration in relation to 46 (Figure 1A). There was grade I mobility in relation to 46 [36]. The probing depth was $7 \mathrm{~mm}$ in the furcal region in relation to the buccal aspect of 46. Pulp sensibility tests such as electric pulp test (Gentle Pulse ${ }^{\text {TM }}$ Pulp Vitality Tester, Parkell, USA) and cold test (Coltene/Whaledent, Switzerland) showed no response and confirmed that the tooth was non vital. Tenderness on percussion was present in relation to 46 . Radiographic examination using Intra Oral Periapical Radiograph revealed, radiolucency in the coronal aspect involving pulp and periapical radiolucency involving the mesial root of 46 and furcal bone loss suggestive of dislodged restoration and secondary caries with periodontal involvement (Figure 1B). Thus the diagnosis was made as pulp necrosis with symptomatic apical periodontitis in relation to 46 [37] suggestive of primary endodontic lesion with secondary periodontal involvement [38].

\section{Therapeutic Intervention}

Endodontic treatment was taken up first and then periodontal regenerative surgery was planned for treatment of the defect with alloplastic bone substitute and platelet rich fibrin (PRF).

First Visit: Patient was detailed about the treatment protocol, the number of visits, the merits and demerits of this procedure and alternate treatment options were explained in case the treatment failed. A written consent was taken from the patient before starting the procedure. No premedication was given. During the first visit, the patient was administered local anesthetic with vasoconstrictor (2\% lidocaine with 1:100000 epinephrine). Rubber dam isolation was done and access cavity preparation done in 46 (Figure 1C). Working length determination was done using apex locator (J Morita) and confirmed radiographically (Figure 1D). Routine chemomechanical preparation was done in 46 using Protaper Gold Rotary files (Dentsply. Apical preparation was done up to F2 size for mesial canals and up to F3 for distal canal. 3\% sodium hypochlorite, 17\% EDTA and saline were used as irrigants and irrigant activation was performed using Sonic irrigantactivation (Endoactivator), placing the tip, $2 \mathrm{~mm}$ short of the working length. The canals were then dried using sterile paper points and calcium hydroxide (RC Cal, Prime dental products, India) was placed as intracanal medicament. Closed dressing was given using Intermediate restorative material and the patient was recalled after two weeks for obturation.

Second Visit: During the second visit, the intracanal medicament was removed from the root canals and cleaning and shaping and irrigation protocol was repeated using 3\% sodium hypochlorite and $17 \%$ EDTA final rinse for smear layer removal. The canals were then dried using sterile paper points and obturation was done using $6 \%$ gutta percha cones and $\mathrm{AH}$ plus sealer (Figure $1 \mathrm{E}, \mathrm{F})$. There was sealer extrusion seen in relation to mesial root of 46 (Figure 1F). The patient was administered pain analgesics (Zerodol P) twice a day for two days. Patient was recalled after 2 weeks for surgical management of furcal defect.

Third Visit: When the patient reported after 2 weeks, the patient was completely asymptomatic but the probing depth was persistent (Figure 2A). The area selected for flap surgery was anesthetized using lignocaine with adrenaline 1: 1,50,000. A full thickness mucoperiosteal flap was elevated at the buccal aspect following intracrevicular incision in relation to 46 and the furcal defect was assessed (Figure 2B). The necrotic tissue was completely debrided using Gracey curettes \#1-2 and 3-4, until the bleeding stopped. There were greenish calculus deposits found in the roots. Ultrasonic scalertips (Satelac, Acteon) were used to remove the calculus and root planning was done. Mean while, $10 \mathrm{ml}$ of patient's blood was collected and centrifuged for PRF [18, 39]. The PRF was made in to a membrane. Bovine derived xenograft (Bio-Oss) was used [40]. The bone graft mixed with blood from PRF (Figure 2C) and was packed well into the furcal bony defect area and the PRF membrane was placed over it (Figure 2D,E). The flap was

Figure 1. Endodontic intervention - (A) Preoperative clinical picture, (B) Preoperative IOPAR, (C) Access cavity picture, (D) Working length IOPAR, (E) Master cone IOPAR, (F) Obturation IOPAR.

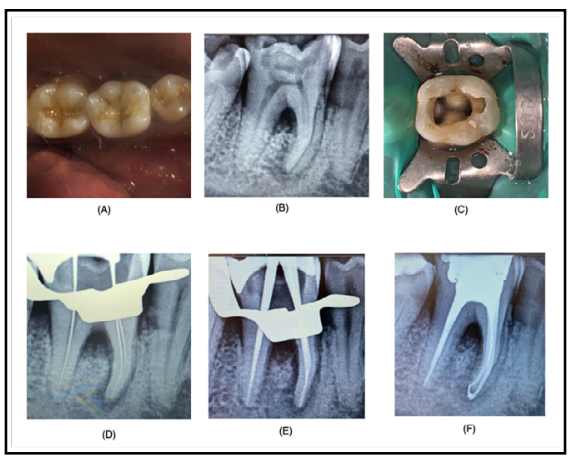


Figure 2. Periodontal surgery as intervention- (A) Preoperative probing depths, (B) Flap elevation and curettage of the furcal defect, (C) Bone graft with PRF, (D) Bone graft placement at the site of defect, (E) Placement of membrane, (F) Suturing.

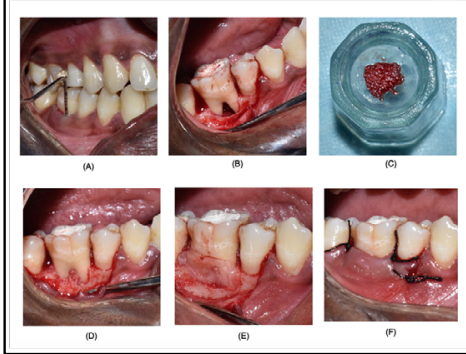

Figure 3. Follow up at 1 year (A) Clinical picture, (B) IOPAR.

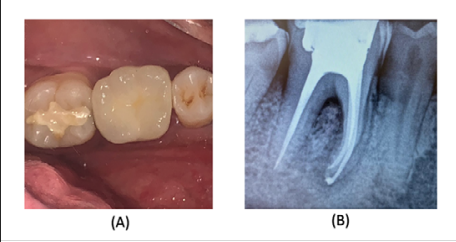

then approximated with non resorbable black silk (3-0) suture using interrupted suturing technique and periodontal dressing was placed (Figure 2F). The patient was advised antibiotics for 5 days and was recalled after a week for suture removal. Permanent full coverage restoration was planned after 3 to 6 months after the uneventful repair of the endoperio lesion (Figure 3A).

\section{Follow Up And Outcome}

The follow up schedule was given to the patient at 1, 3, 6 and 12 months according to Merin's classification [41, 42]. The outcomes to be assessed include absence of mobility, reduction in probing depth, radiographic resolution of periapical and furcal radiolucency due to bone fill. Both clinical and radiological outcomes were successful at one year follow up. The probing depth was reduced to $2 \mathrm{~mm}$, there was good healing of the surgical site. Radiographically, substantial bone fill was seen in the periapical lesion of mesial root of 46 as well as the furcal defect (Figure 3B). The sealer extrusion in relation to mesial roots have also resolved [43].

\section{Discussion}

The diagnosis of the key etiological factor is of prime importance in establishing the diagnosis of endo-perio lesions. The primary causative factor of the disease is microbial invasion and the rapidity of disease progression depends on the microbes present and its virulence.

The persistent nature of the endodontic pathogens is mainly due to biofilm formation which makes them firmly adherent to the root canal walls and this organised structure also makes them resistant to intracanal medicaments. Hence in our case, we have activated the irrigant sonically in order to facilitate biofilm removal as well as for the irrigant to reach all the inaccessible areas of the complex root canal system [44]. In many cases of endoperio cases with primary endodontic involvement, the periodontal regeneration occurs once the root canal treatment is performed. But in cases of furcation involvement, the rate of healing is hindered by the microbes still hiding in the inaccessible furcation areas [45].
In order to facilitate healing of the furcal bony defect, bone graft (xenograft) was placed which is osteoconductive in nature [46]. It serves as a matrix for bone growth. Platelet rich fibrin is an autologous platelet concentrate, which is rich in growth factors and highly biocompatible avoiding the possibility of immune rejection. PRF is a second generation platelet concentrate and is capable of progressive and sustained release of cytokines, TGF- $\beta$, PDGF in high concentrations during remodeling of fibrin matrix. It may also be used as a membrane to stabilize the bone graft [39, 47]. Bone grafts may be autografts, allografts or xenografts that are osteoinductive or osteoconductive [20].

Thus the treatment of endoperio lesion requires both endodontic treatment as well as periodontal regenerative procedures to achieve long term good prognosis of the treated tooth. The treatment strategy primarily should focus on disinfection of the root canal system followed by an observational period. The goal of periodontal flap surgery is to debride all the necrotic tissues from the surgical site and facilitate the regeneration of hard and soft tissues along with the formation of new connective tissue apparatus [48].

Our institution is passionate about high quality evidence based research and has excelled in various fields [25, 49-58]. This has us to apply the concepts of autologous platelet concentrates in improving healing outcomes of endoperio lesions.

\section{Acknowledgement and Declaration}

I would like to acknowledge my mentors and guide for helping me in case selection and treatment planning and the lab facilities for PRF preparation.

\section{Conclusion}

Multivisit endodontic therapy along with autologous platelet-rich derivatives and alloplastic bone substitute resulted in successful, clinical and radiological outcomes at one year follow up. There was gain in clinical attachment, reduction in probing depth, and radiographic bone fill and good healing of the surgical site. 


\section{References}

[1]. Rotstein I, Simon JH. Diagnosis, prognosis and decision-making in the treatment of combined periodontal-endodontic lesions. Periodontol 2000. 2004;34:165-203. PubmedPMID: 14717862.

[2]. Simring M, Goldberg M. The pulpal pocket approach: retrograde periodontitis. The Journal of Periodontology. 1964 Jan;35(1):22-48.

[3]. Singh P. Endo-perio dilemma: a brief review. Dent Res J (Isfahan). 2011 Winter;8(1):39-47. PubmedPMID: 22132014

[4]. Parolia A, Gait TC, Porto IC, Mala K. Endo-perio lesion: A dilemma from 19 th until 21 st century. Journal of Interdisciplinary Dentistry. 2013 Jan $1 ; 3(1): 2$.

[5]. Narang S, Narang A, Gupta R. A sequential approach in treatment of perioendo lesion. J Indian SocPeriodontol. 2011 Apr;15(2):177-80. PubmedPMID: 21976845.

[6]. Simon JH, Glick DH, Frank AL. The relationship of endodontic-periodontic lesions. J Endod. 2013 May;39(5):e41-6. PubmedPMID: 23611400.

[7]. Lowman JV, Burke RS, Pelleu GB. Patent accessory canals: incidence in molar furcation region. Oral Surg Oral Med Oral Pathol. 1973 Oct;36(4):5804. PubmedPMID: 4517107.

[8]. Gutmann JL. Prevalence, location, and patency of accessory canals in the furcation region of permanent molars. J Periodontol. 1978 Jan;49(1):21-6. PubmedPMID: 271710.

[9]. Burch JG, Hulen S. A study of the presence of accessory foramina and the topography of molar furcations. Oral Surg Oral Med Oral Pathol. 1974 Sep;38(3):451-5. PubmedPMID: 4528398.

[10]. De Deus QD. Frequency, location, and direction of the lateral, secondary, and accessory canals. J Endod. 1975 Nov;1(11):361-6. PubmedPMID: 10697487.

[11]. Goldberg F, Massone EJ, Soares I, Bittencourt AZ. Accessory orifices: anatomical relationship between the pulp chamber floor and the furcation. J Endod. 1987 Apr;13(4):176-81. PubmedPMID: 3471840.

[12]. Whyman RA. Endodontic-periodontic lesions. Part I: Prevalence, aetiology, and diagnosis. N Z Dent J. 1988 Jul;84(377):74-7. PubmedPMID: 3067159.

[13]. SELTZER S, BENDER IB, ZIONTZ M. THE INTERRELATIONSHIP OF PULP AND PERIODONTAL DISEASE. Oral Surg Oral Med Oral Pathol. 1963 Dec;16:1474-90. PubmedPMID: 14090000.

[14]. Seltzer S, Bender IB, Nazimov H, Sinai I. Pulpitis-induced interradicular periodontal changes in experimental animals. J Periodontol. 1967 MarApr;38(2):124-9. PubmedPMID: 4960220.

[15]. Rotstein I, Simon JH. The endo-perio lesion: a critical appraisal of the disease condition. Endodontic Topics. 2006 Mar;13(1):34-56

[16]. Ramamoorthi S, Nivedhitha MS, Divyanand MJ. Comparative evaluation of postoperative pain after using endodontic needle and EndoActivator during root canal irrigation: A randomised controlled trial. AustEndod J. 2015 Aug;41(2):78-87. PubmedPMID: 25195661.

[17]. Paikkatt JV, Aslam S, Sreedharan S, Philomina B, Kannan VP, Madhu S. Efficacy of various intracanal medicaments against aerobic and facultative anaerobic microorganism found in human primary teeth with necrotic pulp: A randomized clinical trial. J Indian SocPedodPrev Dent. 2018 JulSep;36(3):268-272. PubmedPMID: 30246748.

[18]. Choukroun J, Miron RJ. Platelet rich fibrin: a second-generation platelet concentrate. Platelet rich fibrin in regenerative dentistry: Biological background and clinical indications. 2017 Sep 12;1.

[19]. Wang W, Yeung KWK. Bone grafts and biomaterials substitutes for bone defect repair: A review. Bioact Mater. 2017 Jun 7;2(4):224-247. PubmedPMID: 29744432

[20]. Reynolds MA, Aichelmann-Reidy ME, Branch-Mays GL. Regeneration of periodontal tissue: bone replacement grafts. Dent Clin North Am. 2010 Jan;54(1):55-71. PubmedPMID: 20103472.

[21]. Govindaraju L, Gurunathan D. Effectiveness of Chewable Tooth Brush in Children-A Prospective Clinical Study. J ClinDiagn Res. 2017 Mar;11(3):ZC31-ZC34. PubmedPMID: 28511505.

[22]. Christabel A, Anantanarayanan P, Subash P, Soh CL, Ramanathan M, Muthusekhar MR, et al. Comparison of pterygomaxillarydysjunction with tuberosity separation in isolated Le Fort I osteotomies: a prospective, multi-centre, triple-blind, randomized controlled trial. Int J Oral Maxillofac Surg. 2016 Feb;45(2):180-5. PubmedPMID: 26338075

[23]. Soh CL, Narayanan V. Quality of life assessment in patients with dentofacial deformity undergoing orthognathic surgery--a systematic review. Int J Oral Maxillofac Surg. 2013 Aug;42(8):974-80. PubmedPMID: 23702370.

[24]. Mehta M, Deeksha, Tewari D, Gupta G, Awasthi R, Singh H, et al. Oligonucleotide therapy: An emerging focus area for drug delivery in chronic inflammatory respiratory diseases. ChemBiol Interact. 2019 Aug 1;308:206-
215. PubmedPMID: 31136735.

[25]. Ezhilarasan D, Apoorva VS, Ashok Vardhan N. Syzygiumcumini extract induced reactive oxygen species-mediated apoptosis in human oral squamous carcinoma cells. J Oral Pathol Med. 2019 Feb;48(2):115-121. PubmedPMID: 30451321.

[26]. Campeau PM, Kasperaviciute D, Lu JT, Burrage LC, Kim C, Hori M, et al. The genetic basis of DOORS syndrome: an exome-sequencing study. Lancet Neurol. 2014 Jan;13(1):44-58. PubmedPMID: 24291220.

[27]. Kumar S, Sneha S. Knowledge and awareness regarding antibiotic prophylaxis for infective endocarditis among undergraduate dental students. Asian Journal of Pharmaceutical and Clinical Research. 2016;154.

[28]. Christabel SL, Gurunathan D. Prevalence of type of frenal attachment and morphology of frenum in children, Chennai, Tamil Nadu. World J Dent. 2015 Oct;6(4):203-7.

[29]. Kumar S, Rahman RE. Knowledge, awareness, and practices regarding biomedical waste management among undergraduate dental students. Asian Journal of Pharmaceutical and Clinical Research. 2017;10(8):341.

[30]. Sridharan G, Ramani P, Patankar S. Serum metabolomics in oral leukoplakia and oral squamous cell carcinoma. J Cancer Res Ther. 2017 JulSep;13(3):556-561. PubmedPMID: 28862226.

[31]. Ramesh A, Varghese SS, Doraiswamy JN, Malaiappan S. Herbs as an antioxidant arsenal for periodontal diseases. J IntercultEthnopharmacol. 2016 Jan 27;5(1):92-6. PubmedPMID: 27069730.

[32]. Thamaraiselvan M, Elavarasu S, Thangakumaran S, Gadagi JS, Arthie T. Comparative clinical evaluation of coronally advanced flap with or without platelet rich fibrin membrane in the treatment of isolated gingival recession. J Indian SocPeriodontol. 2015 Jan-Feb;19(1):66-71. PubmedPMID: 25810596.

[33]. Thangaraj SV, Shyamsundar V, Krishnamurthy A, Ramani P, Ganesan K, Muthuswami M, et al. Molecular Portrait of Oral Tongue Squamous Cell Carcinoma Shown by Integrative Meta-Analysis of Expression Profiles with Validations. PLoS One. 2016 Jun 9;11(6):e0156582. PubmedPMID: 27280700.

[34]. Ponnulakshmi R, Shyamaladevi B, Vijayalakshmi P, Selvaraj J. In silico and in vivo analysis to identify the antidiabetic activity of beta sitosterol in adipose tissue of high fat diet and sucrose induced type- 2 diabetic experimental rats. ToxicolMech Methods. 2019 May;29(4):276-290. PubmedPMID: 30461321.

[35]. Ramakrishnan M, Bhurki M. Fluoride, Fluoridated Toothpaste Efficacy And Its Safety In Children-Review. International Journal of Pharmaceutical Research. 2018 Oct 1;10(04):109-14.

[36]. Laster L, Laudenbach KW, Stoller NH. An evaluation of clinical tooth mobility measurements. J Periodontol. 1975 Oct;46(10):603-7. PubmedPMID: 1058939 .

[37]. Glickman GN. AAE Consensus Conference on Diagnostic Terminology: background and perspectives. J Endod. 2009 Dec;35(12):1619-20. PubmedPMID: 19932336

[38]. Simon P, Jacobs D. The so-called combined periodontal-pulpal problem. Dent Clin North Am. 1969 Jan;13(1):45-52. PubmedPMID: 5249437.

[39]. M M, Madi M. Platelet Rich Fibrin and Periodontal Tissue Regeneration. Advances in Dentistry \& Oral Health. 2017.

[40]. Hanes PJ. Bone replacement grafts for the treatment of periodontal intrabony defects. Oral MaxillofacSurgClin North Am. 2007 Nov;19(4):499512, vi. PubmedPMID: 18088901.

[41]. Newman MG, Takei H, Perry R. Klokkevold PR, Carranza FA. Carranza’s Clinical Periodontology. 11th ed: Saunders. 2011.

[42]. Newman MG, Takei H, Carranza FA, Klokkevold PR. Clinical Periodontology. Saunders. 2006.

[43]. Kaur A, Shah N, Logani A, Mishra N. Biotoxicity of commonly used root canal sealers: A meta-analysis. J Conserv Dent. 2015 Mar-Apr;18(2):83-8. PubmedPMID: 25829682

[44]. Neelakantan P, Devaraj S, Jagannathan N. Histologic Assessment of Debridement of the Root Canal Isthmus of Mandibular Molars by Irrigant Activation Techniques Ex Vivo. J Endod. 2016 Aug;42(8):1268-72. PubmedPMID: 27339632.

[45]. Aksel H, Serper A. A case series associated with different kinds of endo-perio lesions. J ClinExp Dent. 2014 Feb 1;6(1):e91-5. PubmedPMID: 24596642.

[46]. Albrektsson T, Johansson C.Osteoinduction, osteoconduction and osseointegration. The Use of Bone Substitutes in Spine Surgery. 2002;12-17.

[47]. Dohan DM, Choukroun J, Diss A, Dohan SL, Dohan AJ, Mouhyi J, et al. Platelet-rich fibrin (PRF): a second-generation platelet concentrate. Part I: technological concepts and evolution. Oral Surg Oral Med Oral Pathol Oral RadiolEndod. 2006 Mar;101(3):e37-44. PubmedPMID: 16504849.

[48]. Patel B. Endodontic diagnosis, pathology and treatment planning. Classification of pulp and perio-apical disease. Switzerland: Springer International Publishing. 2015.

[49]. VijayashreePriyadharsini J. In silico validation of the non-antibiotic drugs 
acetaminophen and ibuprofen as antibacterial agents against red complex pathogens. J Periodontol. 2019 Dec;90(12):1441-1448. PubmedPMID: 31257588 .

[50]. J PC, Marimuthu T, C K, Devadoss P, Kumar SM. Prevalence and measurement of anterior loop of the mandibular canal using CBCT: A cross sectional study. Clin Implant Dent Relat Res. 2018 Aug;20(4):531-534. PubmedPMID: 29624863.

[51]. Ramesh A, Varghese S, Jayakumar ND, Malaiappan S. Comparative estimation of sulfiredoxin levels between chronic periodontitis and healthy patients - A case-control study. J Periodontol. 2018 Oct;89(10):1241-1248. PubmedPMID: 30044495.

[52]. Ramadurai N, Gurunathan D, Samuel AV, Subramanian E, Rodrigues SJL. Effectiveness of 2\% Articaine as an anesthetic agent in children: randomized controlled trial. Clin Oral Investig. 2019 Sep;23(9):3543-3550. PubmedPMID: 30552590.

[53]. Sridharan G, Ramani P, Patankar S, Vijayaraghavan R. Evaluation of salivary metabolomics in oral leukoplakia and oral squamous cell carcinoma. J Oral Pathol Med. 2019 Apr;48(4):299-306. PubmedPMID: 30714209.

[54]. Mathew MG, Samuel SR, Soni AJ, Roopa KB. Evaluation of adhesion of Streptococcus mutans, plaque accumulation on zirconia and stainless steel crowns, and surrounding gingival inflammation in primary molars: randomized controlled trial. Clin Oral Investig. 2020 Sep;24(9):3275-3280. PubmedPMID: 31955271.
[55]. Samuel SR. Can 5-year-olds sensibly self-report the impact of developmental enamel defects on their quality of life? Int J Paediatr Dent. 2021 Mar;31(2):285-286. PubmedPMID: 32416620.

[56]. R H, Ramani P, Ramanathan A, R JM, S G, Ramasubramanian A, et al. CYP2 C9 polymorphism among patients with oral squamous cell carcinoma and its role in altering the metabolism of benzo[a]pyrene. Oral Surg Oral Med Oral Pathol Oral Radiol. 2020 Sep;130(3):306-312. PubmedPMID: 32773350.

[57]. Chandrasekar R, Chandrasekhar S, Sundari KKS, Ravi P. Development and validation of a formula for objective assessment of cervical vertebral bone age. ProgOrthod. 2020 Oct 12;21(1):38. PubmedPMID: 33043408.

[58]. VijayashreePriyadharsini J, SmilineGirija AS, Paramasivam A. In silico analysis of virulence genes in an emerging dental pathogen A. baumannii and related species. Arch Oral Biol. 2018 Oct;94:93-98. PubmedPMID: 30015217. 